\title{
Influence of host plant and rice straw as substrate on mass multiplication of arbuscular mycorrhizal fungi for large-scale agricultural application
}

\author{
Nisha Kadian ${ }^{1} \cdot{\text { Kuldeep } \text { Yadav }^{2} \cdot \text { Esha Jangra }^{1} \cdot \text { Ashok Aggarwal }}^{1}[$
}

Received: 16 June 2018 / Accepted: 4 March 2019 / Published online: 20 March 2019

(c) The Author(s) 2019

\begin{abstract}
Purpose Rice straw is a waste product from the harvesting of Oryza sativa L. It is recurrently burned resulting in producing overheating, soil degradation, and air and water pollution.

Methods A pot experiment was designed under polyhouse conditions to evaluate the effects of rice straw as a substrate with Sorghum bicolor (L.) Moench, Hordeum vulgare L. and Triticum aestivum L. as different host on mass multiplication of Glomus mosseae.

Results AM fungi multiplication was greatly influenced by the presence, concentration (0,25,50 or $100 \mathrm{~g} / \mathrm{pot})$ and type of substrates. Soil amendment with compost rice straw proved more suitable for AM fungal multiplication over dry substrate. Sorghum bicolor acts as a suitable host and produced the most inoculum followed by Triticum aestivum.

Conclusion Assessment of the effects of substrates and hosts on the multiplication of pure culture of AM Fungi is an important prerequisite condition for large-scale agricultural application and exploration as biofertilizers.
\end{abstract}

Keywords Glomus mosseae $\cdot$ Oryza sativa $\cdot$ Compost $\cdot$ Hosts $\cdot$ Mass multiplication

\section{Introduction}

The basic objective of farming is to generate high quality food with higher productivity to fulfill the demand of increasing populations in the most sustainable way causing least possible damage to ecosystems. Sustainable development is the only solution to encompass soil and crop productivity, while maintaining ecosystems and biodiversity (Muthukumar and Udaiyan 2002a; Ijdo et al. 2010). One potential way to reduce the negative impact of chemical fertilizers is the use of plant growth promoting rhizobacteria (PGPR). Among microbial communities, endomycorrhizal fungi form a mutualistic association between roots of most plants and fungi of order Glomales involves a large number of events modifying the morphological as well as

Ashok Aggarwal

ashokbotanykuk@gmail.com; nishakadian4@gmail.com

1 Department of Botany, Faculty of Life Sciences, Kurukshetra University, Kurukshetra, Haryana 136119, India

2 Department of Botany, Gandhi Memorial National College, Ambala Cantt, Haryana 133001, India biochemical processes of the two symbionts (Kapoor et al. 2008). Establishment of a symbiotic association between AMF and host plants increases the nutrient bioavailability through mobilization of key nutrients to the crop plants by increasing the nutrient bioavailability through mobilization of key nutrients to the crop plants and reinstating the soil fertility, reducing the negative impact of chemical fertilizers on our environment (Rashid et al. 2016; Wood, 1991).

The broad application of AMF has been restrained by difficulties in obtaining large quantities of pure inoculum and the commercial exploitation is still in its infancy (Kadian et al. 2013). Quantitative and qualitative populations of AMF depend on different cultivation practices adopted for plant growth, environmental conditions, type of suitable substrate and host (Kadian et al. 2018). Selection of suitable substrate for mass production of AMF is important (Ijdo et al. 2010). The use of waste substrates along with traditional substrates (soil-sand mixture) is the classical, cheapest and most-preferred method for mass culture of AM fungi. The inoculum obtained after the process should be first screened in pots and later under field condition for various crops as it is very important that inoculum should be able to colonize plant roots effectively, multiply in the 
substrate and be able to enhance plant growth (Kapoor et al. 2008; Tanwar et al. 2013a, b).

Approximately, $80 \%$ of the world's rice (Oryza sativa L.) is cultivated in developing countries. Rice straw is a waste obtained after the harvest and is mainly consisting of stems, roots and some spikes. Rice straw is rich in polysaccharides, lignin, silica content, nitrogen, cellulose and $\mathrm{K}, \mathrm{Ca}, \mathrm{P}, \mathrm{Fe}$, $\mathrm{Mg}, \mathrm{Na}$, and Mn (Sarnklong et al. 2010). Despite this, it is frequently burned producing soil degradation and air and water pollution (Guzmán et al. 2015).

A more practical approach to use of rice straw waste along with appropriate hosts is needed for higher yield and mass multiplication of AM fungi at low cost. Thus, the project was undertaken to select suitable form (dry and compost) and concentration $(0,25,50 \mathrm{or} 100 \mathrm{~g} / \mathrm{pot})$ of rice straw waste with appropriate hosts (S. bicolor, $H$. vulgare and $T$. aestivum) to choose the best host-substrate combination for maximized mass production of selected AM Fungi (G. mosseae) associated with agricultural crops.

\section{Materials and methods}

\section{Soil characteristics}

The present study was carried out in a polyhouse of Botany Department, Kurukshetra University, Haryana, India. The characteristics of the soil were: sand- $64.2 \%$, silt $-21.81 \%$, clay-3.90\%, starting EC-0.25 dS/m, pH 6.8 , total $\mathrm{N}-0.042 \%$, organic carbon- $0.06 \%$, available $\mathrm{P}-0.0018 \mathrm{~kg} / \mathrm{m}^{2}, \mathrm{~S}-14.80 \mathrm{ppm}$ and $\mathrm{K}-0.022 \mathrm{~kg} / \mathrm{m}^{2}$.

\section{AM fungus isolation and production of starter inoculum}

The AM fungi, Glomus mosseae, is an important dominant AM fungi associated with most of the agricultural crops (Kadian et al. 2013; Yadav et al. 2013a, b; Tanwar et al. 2013a, b). Starter inoculum of the selected AM spores was multiplied on maize (Zea mays L.) for 2 months using the funnel technique method of Menge and Timmer (1982). Rice straw used as substrate was dried (grounded to make a fine powder) or composted (placed in nylon net bags and buried for 3 months). Sorghum (S. bicolor), barley (H. vulgare) and wheat (T. aestivum) were selected as host plants and tested with substrate.

\section{Experimental setup}

The concentrations of substrate $(0,25,50$ or $100 \mathrm{~g} / \mathrm{pot})$ were mixed to earthen pots $(25.4 \times 25 \mathrm{~cm})$ and thoroughly mixed with sterilized sand: soil in a ratio 1:3 (w:w) to make final volume of $2 \mathrm{~kg}$. To each pot, $200 \mathrm{~g}$ of AM inoculum consisting of chopped AM-colonized root pieces of maize, along with soil containing about 350-420 AM spores 100/g, was added.

Ten healthy seeds of S. bicolor, H. vulgare and T. aestivum were sown in each pot above the inoculum. After 15 days of growth, these plants were thinned to five plants per pot. Plants were watered regularly on alternate days and $100 \mathrm{~mL} /$ pot of Hoagland's solution (without $\mathrm{KH}_{2} \mathrm{PO}_{4}$ ) (Hoagland and Arnon 1950) was poured to each pot at 15-day intervals.

\section{Harvest and analysis}

Plant vegetative growth was observed after 90 days of plantation. Plants were manually uprooted to measure their height and root length. The plants were washed in running tap water. Roots and shoots were separated to note their fresh weight and then placed in an oven to dry at $70{ }^{\circ} \mathrm{C}$ until a constant dry weight was obtained. The percent of AM root colonization and AM spore counts was calculated using the method of Philips and Hayman (1970) and Gerdemann and Nicolson (1963).

\section{Statistical analysis}

The present experiment was a $4 \times 2 \times 3$ factorial in a completely randomized design with each treatment replicated five times. The statistical analysis of data was subjected to analysis of variance (ANOVA) in SPSS (ver. 11.5, SPSS Inc., Chicago, IL, USA). Means were separated using Duncan's multiple range test.

\section{Results and discussion}

The stability of plant growth is considered as a vital factor for endomycorrhizal fungal production. It is evident from the results that although all the host plants inoculated with G. mosseae produced fungal spores and colonized roots that were characterized by the presence of extrametrical hyphae, intraradical hyphae, arbuscules and vesicles yet substantial differences were obtained with different substrate types as well as various host plants.

When barley was used as a host and rice straw as substrate, results of the study depicted that host plant greatly influenced sporulation and root colonizing ability of G. mosseae. $50 \mathrm{~g}$ dry substrate resulted in the greatest plant growth in terms of plant height, while the plant biomass, root length and maximum spore number and root colonization were found to be maximum at $100 \mathrm{~g}$ (Tables 1 and 2). Barley acts as a suitable host for increasing AM inoculum density due to its short life span, better root architecture, colonization level and tolerance to low levels of soil phosphorus 
Table 1 Efficacy of various forms of rice straw substrate and their different concentrations on plant growth parameters of $H$. vulgare for inoculum production of $G$. mosseae

\begin{tabular}{|c|c|c|c|c|c|c|c|}
\hline Type of rice straw substrate & $\begin{array}{l}\text { Conc. of each } \\
\text { substrate (g/ } \\
\text { pot) }\end{array}$ & Plant height $(\mathrm{cm})$ & $\begin{array}{l}\text { Fresh shoot } \\
\text { weight (g) }\end{array}$ & $\begin{array}{l}\text { Dry shoot } \\
\text { weight } \\
(\mathrm{gm})\end{array}$ & Root length $(\mathrm{cm})$ & $\begin{array}{l}\text { Fresh root } \\
\text { weight }(\mathrm{g})\end{array}$ & Dry root weight $(\mathrm{g})$ \\
\hline \multirow[t]{4}{*}{ Dry } & 0 & $19.6 \mathrm{f}$ & $2.728 \mathrm{e}$ & $0.62 \mathrm{~h}$ & $11.8 \mathrm{~h}$ & $2.36 f$ & $0.93 \mathrm{~g}$ \\
\hline & 25 & $24.0 \mathrm{e}$ & $2.946 \mathrm{~d}$ & $0.93 \mathrm{~g}$ & $14.0 \mathrm{f}$ & $2.68 \mathrm{~d}$ & $0.97 f$ \\
\hline & 50 & $30.0 \mathrm{c}$ & $3.038 \mathrm{~h}$ & $1.25 \mathrm{f}$ & $17.2 \mathrm{e}$ & $2.73 \mathrm{c}$ & $0.98 \mathrm{e}$ \\
\hline & 100 & $25.6 \mathrm{e}$ & $3.244 \mathrm{~g}$ & $1.35 \mathrm{e}$ & $22.4 \mathrm{~b}$ & $2.94 b$ & $1.02 \mathrm{de}$ \\
\hline \multirow[t]{4}{*}{ Compost } & 0 & $29.0 \mathrm{~d}$ & $3.268 \mathrm{f}$ & $1.62 \mathrm{~d}$ & $12.4 \mathrm{~g}$ & $2.49 \mathrm{e}$ & $1.03 \mathrm{~d}$ \\
\hline & 25 & $32.4 \mathrm{c}$ & $3.384 \mathrm{c}$ & $1.78 \mathrm{c}$ & $19.6 \mathrm{~d}$ & $2.74 \mathrm{c}$ & $1.21 \mathrm{c}$ \\
\hline & 50 & $35.4 \mathrm{~b}$ & $3.430 \mathrm{~b}$ & $1.85 \mathrm{~b}$ & $21.2 \mathrm{c}$ & $2.94 b$ & $1.26 \mathrm{~b}$ \\
\hline & 100 & $38.2 \mathrm{a}$ & $3.930 \mathrm{a}$ & $1.95 \mathrm{a}$ & $25.4 \mathrm{a}$ & $3.02 \mathrm{a}$ & $1.41 \mathrm{a}$ \\
\hline $\operatorname{LSD}(P \leq 0.05)$ & & 1.6905 & 0.4045 & 1.0261 & 1.4012 & 0.2101 & 0.2104 \\
\hline \multirow[t]{3}{*}{$\operatorname{ANOVA} F_{(7,15)}$} & $\mathrm{S}^{\mathrm{a}}$ type & 67.238 & 5.237 & 23.765 & 3.366 & 5.559 & 21.650 \\
\hline & S conc. & 34.221 & 72.634 & 50.872 & 168.006 & 181.194 & 120.144 \\
\hline & $\mathrm{S}$ type $\times \mathrm{S}$ conc. & 54.309 & 123.263 & 33.548 & 238.428 & 32.761 & 33.767 \\
\hline
\end{tabular}

$S$ substrate

*Values in a column followed by same letter are not significantly different, least significant different test, $P \leq 0.05$

Table 2 Effect of rice straw substrate (Dry and Compost) on colonization and spore population of G. mosseae in $H$. vulgare

\begin{tabular}{|c|c|c|c|c|c|c|}
\hline & \multirow{3}{*}{$\begin{array}{l}\text { Conc. of each } \\
\text { substrate }\left(\mathrm{g} \mathrm{pot}^{-1}\right) \\
0\end{array}$} & \multirow{2}{*}{\multicolumn{3}{|c|}{ 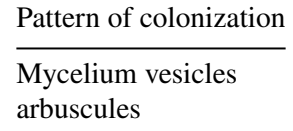 }} & & \multirow{3}{*}{$\begin{array}{l}\% \text { Root } \\
\text { coloniza- } \\
\text { tion }\end{array}$} \\
\hline & & & & & & \\
\hline & & \multirow{4}{*}{$\begin{array}{l}+ \\
+ \\
+\end{array}$} & \multirow{2}{*}{$\begin{array}{l}- \\
++\end{array}$} & & & \\
\hline $\begin{array}{l}\text { Type of rice straw substrate } \\
\text { Dry }\end{array}$ & 25 & & & & $\begin{array}{l}\text { AM spore num- } \\
\text { ber/10 g of soil }\end{array}$ & $71.0 \mathrm{e}$ \\
\hline & 50 & & +++ & +++ & $200.0 \mathrm{e}$ & $91.8 \mathrm{c}$ \\
\hline & 100 & & ++ & ++ & $221.0 \mathrm{c}$ & $93.4 b$ \\
\hline \multirow[t]{4}{*}{ Compost } & 0 & + & ++ & + & $70.60 \mathrm{~g}$ & $51.6 \mathrm{f}$ \\
\hline & 25 & + & + & + & $211.0 \mathrm{~d}$ & $83.0 \mathrm{~d}$ \\
\hline & 50 & + & + & ++ & $258.4 \mathrm{~b}$ & $95.0 \mathrm{ab}$ \\
\hline & 100 & + & +++ & +++ & $291.0 \mathrm{a}$ & $96.8 \mathrm{a}$ \\
\hline \multicolumn{2}{|l|}{ L.S.D $(P \leq 0.05)$} & & & & 21.0561 & 9.5192 \\
\hline \multirow[t]{3}{*}{ ANOVA $F_{(7,15)}$} & \multicolumn{4}{|l|}{ S type } & 180.012 & 77.680 \\
\hline & \multicolumn{4}{|l|}{ S conc. } & 38.468 & 45.107 \\
\hline & \multicolumn{4}{|l|}{$S$ type $\times S$ conc. } & 16.772 & 12.762 \\
\hline
\end{tabular}

Each value is a mean of five replicates, $S$ substrate, $A M$ arbuscular mycorrhizae, - absent, + scanty, ++ moderate, +++ abundant

*Indicates the level of significance at $(P \leq 0.05)$ level

Means followed by same letter/s within a column are not significantly different over one another (least significant different test $(P \leq 0.05)$
(Ijdo et al. 2010). But the application of compost substrate at $100 \mathrm{~g}$ resulted in maximum plant height, spore number and root colonization (Tables 1 and 2). Labidi et al. (2007) noticed an increased the AM fungal population using Acacia tortilis leaves compost to eroded soil. Muthukumar and Udaiyan (2002b) also reported an enhancement in the AM spore population when they used compost as a substrate.

Likewise, wheat plant inoculated with AM fungi using different concentrations $(0,25,50$ or $100 \mathrm{~g} /$ pot $)$ of substrates showed stimulatory effect on plant growth, biomass and mycorrhization. Application of $100 \mathrm{~g}$ dry substrate significantly resulted in maximum plant height, while maximum AM spore number and root colonization were observed with $50 \mathrm{~g}$ dry substrate (Tables 3,4$)$. Generally, with an increase in the growth period after infection, root colonization of host also increases. However, this increase in colonization and period does not have greater bearing on AMF spore production. Again in wheat, compost substrate, irrespective of the 
Table 3 Efficacy of various forms of rice straw substrate and their different concentrations on plant growth parameters of $T$. aestivum for inoculum production of G. mosseae

\begin{tabular}{|c|c|c|c|c|c|c|c|}
\hline Type of rice straw substrate & $\begin{array}{l}\text { Conc. of each } \\
\text { substrate }(\mathrm{g} / \mathrm{pot})\end{array}$ & Plant height $(\mathrm{cm})$ & $\begin{array}{l}\text { Fresh shoot } \\
\text { weight }(\mathrm{gm})\end{array}$ & $\begin{array}{l}\text { Dry shoot } \\
\text { weight (gm) }\end{array}$ & Root length (cm) & $\begin{array}{l}\text { Fresh root } \\
\text { weight }(\mathrm{gm})\end{array}$ & $\begin{array}{l}\text { Dry root } \\
\text { weight } \\
\text { (gm) }\end{array}$ \\
\hline \multirow[t]{4}{*}{ Dry } & 0 & $27.4 \mathrm{~g}$ & $3.604 f$ & $1.00 \mathrm{~g}$ & $09.20 \mathrm{~h}$ & $1.47 \mathrm{~h}$ & $0.484 \mathrm{~h}$ \\
\hline & 25 & $32.4 \mathrm{e}$ & $3.948 d$ & $1.20 \mathrm{~d}$ & $19.22 \mathrm{c}$ & $3.94 d$ & $2.184 b$ \\
\hline & 50 & $40.8 \mathrm{c}$ & $8.908 \mathrm{a}$ & $3.26 \mathrm{~b}$ & $13.30 \mathrm{e}$ & $3.83 \mathrm{e}$ & $1.250 \mathrm{e}$ \\
\hline & 100 & $52.2 \mathrm{a}$ & $8.438 \mathrm{~b}$ & $3.40 \mathrm{a}$ & $10.36 \mathrm{~g}$ & $2.00 \mathrm{f}$ & $0.684 f$ \\
\hline \multirow[t]{4}{*}{ Compost } & 0 & $28.0 \mathrm{~g}$ & $3.826 \mathrm{e}$ & $1.02 \mathrm{f}$ & $12.11 \mathrm{f}$ & $1.64 \mathrm{~g}$ & $0.666 \mathrm{~g}$ \\
\hline & 25 & $34.2 \mathrm{~d}$ & $4.508 \mathrm{c}$ & $1.05 \mathrm{e}$ & $15.34 d$ & $4.00 \mathrm{c}$ & $2.136 \mathrm{~d}$ \\
\hline & 50 & $45.2 \mathrm{~b}$ & $3.282 \mathrm{~g}$ & $1.23 \mathrm{c}$ & $22.27 \mathrm{~b}$ & $4.04 \mathrm{~b}$ & $2.154 \mathrm{c}$ \\
\hline & 100 & $31.8 \mathrm{f}$ & $3.146 \mathrm{~h}$ & $1.21 \mathrm{~d}$ & $28.42 \mathrm{a}$ & $4.81 \mathrm{a}$ & $2.942 \mathrm{a}$ \\
\hline $\operatorname{LSD}(P \leq 0.05)$ & & 6.1225 & 0.3494 & 1.1593 & 1.4131 & 0.5946 & 0.4677 \\
\hline \multirow[t]{3}{*}{ ANOVA $F_{(7,15)}$} & S type & 45.556 & 127.228 & 166.780 & 44.876 & 81.690 & 50.280 \\
\hline & S conc. & 182.580 & 218.726 & 213.342 & 162.884 & 673.94 & 553.28 \\
\hline & $S$ type $\times S$ conc. & 24.776 & 55.541 & 77.245 & 31.601 & 121.55 & 12.566 \\
\hline
\end{tabular}

Each value is a mean of five replicates, \pm : standard deviation, $S$ substrate

*Indicates the level of significance at $(P \leq 0.05)$ level

Means followed by same letter/s within a column are not significantly different over one another (least significant different test $(P \leq 0.05)$

Table 4 Effect of rice straw substrate (Dry and Compost) on colonization and spore population of G. mosseae in $T$. aestivum

\begin{tabular}{|c|c|c|c|c|c|c|}
\hline \multirow{3}{*}{$\begin{array}{l}\text { Type of rice straw substrate } \\
\\
\text { Dry }\end{array}$} & \multirow{3}{*}{$\begin{array}{l}\text { Conc. of each } \\
\text { substrate }\left(\mathrm{g} \mathrm{pot}^{-1}\right) \\
0\end{array}$} & \multirow{2}{*}{\multicolumn{3}{|c|}{$\begin{array}{l}\text { Pattern of Coloniza- } \\
\text { tion } \\
\begin{array}{l}\text { Mycelium Vesicles } \\
\text { Arbuscules }\end{array}\end{array}$}} & \multirow{3}{*}{$\begin{array}{l}\text { AM spore number } \\
60.4 \mathrm{~h}\end{array}$} & \multirow{3}{*}{$\begin{array}{l}\% \text { Root } \\
\text { coloniza- } \\
\text { tion }\end{array}$} \\
\hline & & & & & & \\
\hline & & + & - & + & & \\
\hline & 25 & + & ++ & ++ & $95.8 \mathrm{e}$ & $55.0 \mathrm{~d}$ \\
\hline & 50 & + & + & + & $202.4 \mathrm{c}$ & $100.0 \mathrm{a}$ \\
\hline & 100 & + & - & + & $82.2 \mathrm{f}$ & $50.0 \mathrm{e}$ \\
\hline Compost & 0 & + & + & + & $077.6 \mathrm{~g}$ & $26.00 \mathrm{~g}$ \\
\hline & 25 & + & + & + & $235.2 b$ & $71.8 \mathrm{c}$ \\
\hline & 50 & + & + & ++ & $109.0 \mathrm{~d}$ & $86.8 \mathrm{~b}$ \\
\hline & 100 & + & +++ & ++ & $302.8 \mathrm{a}$ & $100.0 \mathrm{a}$ \\
\hline L.S.D $(P \leq 0.05)$ & & & & & 15.7951 & 7.3281 \\
\hline ANOVA $F_{(7,15)}$ & S type & & & & 12.453 & 22.45 \\
\hline & S conc. & & & & 253.182 & 93.525 \\
\hline & $S$ type $\times S$ conc. & & & & 13.801 & 17.228 \\
\hline
\end{tabular}

Each value is a mean of five replicates, \pm standard deviation, $S$ substrate, $A M$ arbuscular mycorrhizae, absent, + scanty, ++ moderate, +++ abundant

*Indicates the level of significance at $(P \leq 0.05)$ level

Means followed by same letter/s within a column are not significantly different over one another (least significant different test $(P \leq 0.05)$ concentration, was always proved to be stimulatory over the unamended control. The maximum spore number and root colonization were recorded in the rhizosphere of the wheat plants supplemented with $100 \mathrm{~g}$ compost substrate. The variation in the capacity of host plant for mass multiplication of mycorrhizal fungi might be due to the specific variation in host plant root type, its anatomy and morphology, nutrient and endogenous hormone level characteristics and the environmental interaction (Liu and Wang, 2003).

In Sorghum, $50 \mathrm{~g}$ of rice straw substrate, irrespective of the concentration, resulted in maximum plant height, maximum spore number and root colonization (Tables 5 and 6). The massive and dense root system of Sorghum showed good results than other two host plants. Likewise, 
Table 5 Efficacy of various forms of rice straw substrate and their different concentrations on plant growth parameters of $S$. bicolor for inoculum production of G. mosseae

\begin{tabular}{|c|c|c|c|c|c|c|c|}
\hline Type of rice straw substrate & $\begin{array}{l}\text { Conc. of each } \\
\text { substrate (g } \\
\left.\text { pot }^{-1}\right)\end{array}$ & Plant height $(\mathrm{cm})$ & $\begin{array}{l}\text { Fresh shoot } \\
\text { weight }(\mathrm{gm})\end{array}$ & $\begin{array}{l}\text { Dry shoot } \\
\text { weight }(\mathrm{gm})\end{array}$ & Root length (cm) & $\begin{array}{l}\text { Fresh root } \\
\text { weight }(\mathrm{gm})\end{array}$ & $\begin{array}{l}\text { Dry root } \\
\text { weight } \\
(\mathrm{gm})\end{array}$ \\
\hline \multirow[t]{4}{*}{ Dry } & 0 & $71.0 \mathrm{~d}$ & $11.68 \mathrm{f}$ & $3.90 \mathrm{~g}$ & $09.93 \mathrm{~h}$ & $2.04 \mathrm{f}$ & $0.57 \mathrm{~h}$ \\
\hline & 25 & $81.0 \mathrm{c}$ & $16.00 \mathrm{~d}$ & $4.03 \mathrm{e}$ & $19.25 \mathrm{e}$ & $4.93 b$ & $2.26 \mathrm{~b}$ \\
\hline & 50 & $86.4 b$ & $13.42 \mathrm{e}$ & $3.96 f$ & $14.52 \mathrm{f}$ & $4.28 \mathrm{c}$ & $1.35 \mathrm{e}$ \\
\hline & 100 & $97.0 \mathrm{a}$ & $09.26 \mathrm{~g}$ & $2.54 \mathrm{~h}$ & $11.74 \mathrm{~g}$ & $1.42 \mathrm{~g}$ & $0.63 \mathrm{~g}$ \\
\hline \multirow[t]{4}{*}{ Compost } & 0 & $55.2 \mathrm{~g}$ & $16.10 \mathrm{~d}$ & $4.24 d$ & $20.24 d$ & $1.73 \mathrm{~h}$ & $0.70 \mathrm{f}$ \\
\hline & 25 & $60.5 f$ & $22.34 \mathrm{c}$ & $8.27 \mathrm{c}$ & $22.40 \mathrm{c}$ & $4.21 \mathrm{e}$ & $2.07 \mathrm{~d}$ \\
\hline & 50 & $68.4 \mathrm{e}$ & $23.80 \mathrm{~b}$ & $8.96 b$ & $25.26 \mathrm{~b}$ & $4.26 \mathrm{~d}$ & $2.12 \mathrm{c}$ \\
\hline & 100 & $47.0 \mathrm{~h}$ & $26.04 \mathrm{a}$ & $9.81 \mathrm{a}$ & $28.16 \mathrm{a}$ & $4.99 \mathrm{a}$ & $3.03 \mathrm{a}$ \\
\hline $\operatorname{LSD}(P \leq 0.05)$ & & 5.6735 & 4.6038 & 0.9374 & 3.8833 & 0.3077 & 0.2619 \\
\hline \multirow[t]{3}{*}{ ANOVA $F_{(7,15)}$} & S type & 97.969 & 23.787 & 66.043 & 30.752 & 332.756 & 136.289 \\
\hline & S conc. & 887.54 & 459.55 & 327.21 & 87.324 & 543.034 & 54.105 \\
\hline & $\mathrm{S}$ type $\times \mathrm{S}$ conc. & 23.776 & 12.654 & 4.537 & 16.443 & 23.650 & 11.543 \\
\hline
\end{tabular}

Each value is a mean of five replicates, \pm : standard deviation, $S$ substrate

*Indicates the level of significance at $(P \leq 0.05)$ level

Means followed by same letter/s within a column are not significantly different over one another (least significant different test $(P \leq 0.05)$

Table 6 Effect of rice straw substrate (Dry and Compost) on colonization and spore population of G. mosseae in $S$. bicolor

\begin{tabular}{|c|c|c|c|c|c|c|}
\hline \multirow{3}{*}{$\begin{array}{l}\text { Type of rice straw substrate } \\
\text { Dry }\end{array}$} & \multirow{3}{*}{$\begin{array}{l}\text { Conc. of each sub- } \\
\text { strate }\left(\mathrm{g} \mathrm{pot}^{-1}\right) \\
0\end{array}$} & \multirow{2}{*}{\multicolumn{3}{|c|}{$\begin{array}{l}\text { Pattern of Colonization } \\
\text { Mycelium Vesicles } \\
\text { Arbuscules }\end{array}$}} & \multirow{3}{*}{$\begin{array}{l}\text { AM spore num- } \\
\text { ber/10 g of soil } \\
051.0 \mathrm{~h}\end{array}$} & \multirow{3}{*}{$\begin{array}{l}\% \text { Root } \\
\text { coloniza- } \\
\text { tion }\end{array}$} \\
\hline & & & & & & \\
\hline & & \multirow{3}{*}{$\begin{array}{l}+ \\
+ \\
+ \\
+\end{array}$} & - & + & & \\
\hline & 25 & & ++ & ++ & $134.8 \mathrm{~d}$ & $62.4 \mathrm{e}$ \\
\hline & 50 & & ++ & + & $300.8 b$ & $97.0 \mathrm{~b}$ \\
\hline & 100 & + & - & + & $68.40 \mathrm{~g}$ & $52.4 \mathrm{~g}$ \\
\hline \multirow[t]{4}{*}{ Compost } & 0 & + & + & + & $77.8 \mathrm{f}$ & $60.4 \mathrm{f}$ \\
\hline & 25 & + & +++ & + & $212.4 \mathrm{c}$ & $86.8 \mathrm{c}$ \\
\hline & 50 & + & ++ & ++ & $403.4 \mathrm{a}$ & $101.4 \mathrm{a}$ \\
\hline & 100 & + & ++ & ++ & $116.4 \mathrm{e}$ & $68.6 \mathrm{~d}$ \\
\hline \multicolumn{2}{|l|}{$\operatorname{LSD}(P \leq 0.05)$} & & & & 9.408 & 6.651 \\
\hline \multirow[t]{3}{*}{ ANOVA $F_{(7,15)}$} & \multicolumn{4}{|l|}{ S type } & 50.460 & 76.485 \\
\hline & \multicolumn{4}{|l|}{ S conc. } & 551.56 & 349.44 \\
\hline & \multicolumn{4}{|l|}{$S$ type $\times S$ conc. } & 6.454 & 23.763 \\
\hline
\end{tabular}

Each value is a mean of five replicates, \pm standard deviation, $S$ substrate, AM Arbuscular mycorrhizae, absent, + scanty, ++ moderate, +++ abundant

*Indicates the level of significance at $(P \leq 0.05)$ level

Means followed by same letter/s within a column are not significantly different over one another (Least significant different test $(P \leq 0.05)$
Kadian et al. (2018) reported significant increment in the root colonization and AM spore number while using sorghum as host and chickpea husk as substrate. Such difference may be due to the environmental conditions and other biotic factors. Moreover, the suitability of these species could be due to the production of a wide variety of water soluble and volatile organic compounds that may act as stimulant, attractants, nutritional sources, and even as genetic regulatory signals for AM fungi for better colonization (Douds et al. 2010). Chaiyasen et al. (2017) have also reported that AMF root colonization is directly proportional to root growth of host plant. As this waste enhances the nutrient uptake, thereby improving the root system, which favorably enhance the spore population in its surroundings and promotes plant growth (Lin et al. 2012). 


\section{Conclusion}

In summary, soil amendment with compost rice straw proved more suitable for AM fungal multiplication over dry substrate. S. bicolor acts as a most suitable host and produced the most inoculum followed by $T$. aestivum. Assessment of the effects of substrates and hosts on AM fungi production might be useful in developing a package of practices for agricultural crops, which can be explicitly used for the maintenance of sustainable plant productive systems. However, in the present investigation, all the three hosts screened are very common and easily available. Any of the host can be exploited by farmers with rice straw (in any form) for the mass production of G. mosseae, encouraging them to take full benefits of this classical, attractive and alternative cost-effective method.

Acknowledgements The authors are grateful to Kurukshetra University, Kurukshetra for providing laboratory facilities and financial assistance to carry out the research work.

Open Access This article is distributed under the terms of the Creative Commons Attribution 4.0 International License (http://creativeco mmons.org/licenses/by/4.0/), which permits unrestricted use, distribution, and reproduction in any medium, provided you give appropriate credit to the original author(s) and the source, provide a link to the Creative Commons license, and indicate if changes were made.

\section{References}

Chaiyasen A, Leardwiriyakool C, Douds DD, Lumyong S (2017) Influence of host plants and soil diluents on arbuscular mycorrhizal fungus propagation for on-farm inoculum production using leaf litter compost and agrowastes. Biol Agric Hortic 33:52-62. https ://doi.org/10.1080/01448765.2016.1187670

Gerdemann JW, Nicolson YH (1963) Spores of Mycorrhizae endogone species extracted from soil by wet sieving and decanting. Trans Br Mycol Soc 46:235-244. https://doi.org/10.1016/S0007 -1536(63)80079-0

Guzmán ÁS, Delvasto A, Sánchez EV (2015) Valorization of rice straw waste: an alternative ceramic raw material. Cerâmica 61:126-136. https://doi.org/10.1590/0366-69132015613571888

Hoagland DR, Arnon DI (1950) The water culture method for growing plants without soil. California Agricultural Experiment Station Circular 347, University of California, Berkeley

Ijdo M, Cranenbrouck S, Dealerck S (2010) Methods for large scale production of AM fungi: past, present and future. Mycorrhiza 21:1-16. https://doi.org/10.1007/s00572-010-0337-z

Jr. Douds DD, Nagahashi G, Hepperly PR (2010) On Farm Production of inoculum of indigenous arbuscular mycorrhizal fungi and assessment of diluents of compost for inoculum production. Biores Technol 101:2326-2330. https://doi.org/10.1016/j.biort ech.2009.11.071

Kadian N, Yadav K, Aggarwal A (2013) Significance of bioinoculants in promoting growth, nutrient uptake and yield of Cyamopsis tetragonoloba (L.) 'Taub'. Eur J Soil Biol 58:66-72. https://doi. org/10.1016/j.ejsobi.2013.06.001

Kadian N, Yadav K, Aggarwal A (2018) Mass multiplication of arbuscular mycorrhizal fungi associated with some leguminous plants: an ecofriendly approach. Ind J Exp Biol 56:258-266
Kapoor R, Sharma D, Bhatnagar AK (2008) Arbuscular mycorrhizae in micropropagation systems and their potential applications. Sci Hortic 116:227-239. https://doi.org/10.1016/j.scien ta.2008.02.002

Labidi S, Nasr H, Zouaghi M, Wallander H (2007) Effects of compost addition on extra-radical growth of arbuscular mycorrhizal fungi in Acacia tortilis ssp. raddiana savanna in a pre-Saharan area. Appl Soil Ecol 35:184-192. https://doi.org/10.1016/j.apsoi 1.2006.04.009

Lin XG, Feng YZ, Zhang HY, Chen RR, Wang JH, Zhang JB, Chu HY (2012) Long-term balanced fertilization decreases arbuscular mycorrhizal fungal diversity in an arable soil in north China revealed by 454 pyrosequencing. Environ Sci Technol 46:57645771. https://doi.org/10.1021/es3001695

Liu R, Wang F (2003) Selection of appropriate host plant used in trap culture of arbuscular mycorrhizal Fungi. Mycorrhiza 13:123-127. https://doi.org/10.1007/s00572-002-0207-4

Menge JA, Timmer LM (1982) Procedure for inoculation of plants with VAM in the laboratory, greenhouse and field. In: Schenck NC (ed) Methods and principles of mycorrhizal research. American Phytopathological Society, St. Paul, pp 59-68

Muthukumar T, Udaiyan K (2002a) Growth and yield of Cowpea as influenced by changes in arbuscular mycorrhizal fungi in response to organic manuring. J Agron Crop Sci 188:123-132. https://doi. org/10.1046/j.1439-037X.2002.00544.X

Muthukumar T, Udaiyan K (2002b) Arbuscular mycorrhizal fungal composition in semi-arid soils of Western Ghats, Southern India. Mycorrhiza 82:624-627. https://doi.org/10.1007/s005720050274

Philips JM, Hayman DS (1970) Improved procedures for clearing rots and staining parasitic and VAM fungi for rapid assessment of infection. Trans Br Bycol Soc 55:158-161. https://doi. org/10.1016/S0007-1536(70)80110-3

Rashid MI, Mujawar LH, Shahzad T, Almeelbi T, Ismail IM (2016) Bacteria and fungi can contribute to nutrients bioavailability and aggregate formation in degraded soils. Microbiol Res 183:26-41. https://doi.org/10.1016/j.micres.2015.11.007

Sarnklong C, Cone JW, Pellikaan W, Hendriks WH (2010) Utilization of Rice straw and different treatments to improve its feed value for ruminants: a review. Asian-Aust J Anim Sci 23:680-692. https:// doi.org/10.5713/ajas.2010.80619

Tanwar A, Aggarwal A, Parkash V (2013a) Sugarcance bagasse: a novel substrate for mass multiplication of Funneliformis mosseae with onion as host. J Cent Eur Agric 14:1502-1511. https://doi. org/10.5513/jcea01/14.4.1386

Tanwar A, Aggarwal A, Yadav A, Parkash V (2013b) Screening and selection of efficient host and sugarcane bagasse as substrate for mass multiplication of Funneliformis mosseae. Biol Agric Hortic 29:107-117. https://doi.org/10.1080/01448765.2013.771955

Wood TE (1991) VA mycorrhizal fungi: challenges for commercialization. In: Arora DK, Elander RP, Mukerji KG (eds) Handbook of applied mycology, fungal biotechnology, vol 4. Marcel Dekker, New York, pp 823-847

Yadav K, Aggarwal A, Singh N (2013a) Arbuscular mycorrhizal fungi (AMF) induced acclimatization, growth enhancement and colchicine content of micropropagated Gloriosa superba L. plantlets. Ind Crop Prod 45:88-93. https://doi.org/10.1016/j.inder op.2012.12.001

Yadav K, Aggarwal A, Singh N (2013b) Arbuscular mycorrhizal fungi induced acclimatization and growth enhancement of Glycyrrhiza glabra L.: a potential medicinal plant. Agr Res 2:43-47. https:// doi.org/10.1007/s40003-012-0047-1

Publisher's Note Springer Nature remains neutral with regard to jurisdictional claims in published maps and institutional affiliations. 